UDC: $636.22 / .28 .086 .: 612.1$

\title{
PHYSIOLOGICAL STATE AND BLOOD BIOCHEMICAL PARAMETERS OF REPLACEMENT HEIFERS USING TRITICALE VETCH MIXTURES IN RATIONS
}

\author{
H. I. Kotets, T. D. Pushkar, K. R. Mazhilovskaya, K. O. Khamid \\ Odessa State Agrarian University, Odessa, Ukraine
}

Article info

Received 11.03.2019

Received in revised form

25.03.2019

Accepted 01.04.2019

Odessa State Agrarian

University, Odessa, Ukraine Kanatna Str. 99, Odessa,

Odessa region, 65012

E-mail:

odau vetmed@.ukr.net
Kotets, H. I., Pushkar, T. D., Mazhilovskaya, K. R., \& Khamid, K. O. (2019). Physiological state and blood biochemical parameters of replacement heifers using triticale vetch mixtures in rations. Veterinary science, technologies of animal husbandry and nature management, 3, 250255. doi: 10.31890/vttp.2019.03.34

In order to create a stable food supply, increasing the volume of livestock production and improving its quality, high-yielding forage crops are used for the production of green fodder, silage, haylage and hay. But the priority of these crops in terms of land use efficiency, the reduction of energy costs, labour and material resources do not sufficiently take into account. Because of this, the aim of study was to find out the impact of green mass triticale vetch mixtures on the metabolic processes in the body of replacement heifers.

The researches were conducted in, AF «Dniester» Arziz district, Odessa region on the replacement heifers of Ukrainian Red Dairy breed. The experiment on breeding replacement heifers from 8 to 12 months of age was lasted to 90 days. The difference in feeding was that the experimental group of animals were fed on hay and green fodder from triticale vetch mixtures and control one - on hay and green fodder triticale.

Before feeding hay and green fodder were evaluated by organ leptically method. During the experiment food of high quality that meets the requirements of the first class both in the control and experimental group was used.

Hay and green fodder contained nutrients essential for all animals: protein of high quality, easily to enzymatic carbohydrates, fatty acids, vitamins (especially rich in carotene and vitamins $E$ and $B$ complex), minerals and biologically active substances. Besides green fodder has dietary properties.

The dry matter of green fodder for energy and nutrient content of digestible protein is similar to the concentrated feed, while for biological value and the content of biologically active substances it is considerably dominant.

Nutritive value of green mass depends on the phase of vegetation, the botanical composition of grass, on climate conditions and soils. Passing the phases of vegetation the content of protein and fat are decreased in plants and the amount of fiber and MAR are increased. In the early stages of vegetation it is characterized by a higher concentration of 
energy and digestibility of nutrients, higher content of digestible protein, fat, starch, sugar, micro minerals and vitamins. Blood for researches was taken from the jugular vein in three groups of animals in the morning before feeding. Studying the biochemical composition of blood, the amount of phosphorus, calcium, carotene, reserved alkalinity, total protein were investigated. Amount of phosphorus in the blood serum was determined by Brix and the amount of calcium by trylonometrychnyi method.

Carotene content in blood serum was determined by Rachevskyi calorimetric method, alkalinity - by Nevodova (Smirnov, Konopelko, \& Postnikov, 1981).

The total amount of protein in the serum was determined by refractometres method on refractometr $R L U$.

Physiological parameters of heifers body in all groups were within the permissible limits. Body's temperature ranged from 38 to $38,6^{\circ} \mathrm{C}$, pulse rate from 77 to 82 per minute, respiration 25-29, rumination 48-51, large differences were not observed between animals.

Heifers had normal hair but the animals of the experimental group had hair with a specific shine.

It was found that the use of triticale vetch mixtures in the diets of replacement young animals of experimental group has resulted in comparison with the control animals to the calcium's increase in blood by $3.19 \%$, inorganic phosphorus by $2.48 \%$, carotene by $11.3 \%$. The total protein in the heifers blood of experimental group was higher by $5.19 \mathrm{~g} / \mathrm{L}$ compared with the control group.

These data indicate more intensive metabolism of young cattle under the influence of the investigated factors - feeding triticale vetch mixtures.

Carried out researches have shown that the addition of triticale vetch hay and green fodder mixtures in the heifers diets (in phase of budding and flowering) did not cause a violation of physiological state, metabolic and harmful effects on the body as a whole.

Key words: triticale, vetch, mixtures, replacement heifers.

\title{
ФИЗИОЛОГИЧЕСКОЕ СОСТОЯНИЕ И БИОХИМИЧЕСКИЕ ПОКАЗАТЕЛИ КРОВИ РЕМОНТНЫХ ТЕЛОК ПРИ ИСПОЛЬЗОВАНИИ В РАЦИОНАХ ТРИТИКАЛЕВО-ВИКОВОЙ СМЕСИ
}

\author{
Г. И. Котец, Т. Д. Пушкар, К. Р. Мажиловска, К. А. Хамид \\ Одесский государственный аграрный университет, Одесса, Украина
}

Физиологическое состояние и биохимические показатели крови ремонтных телок при использовании в рационах тритикалево-виковой смеси. Исследовано биохимические показатели крови ремонтных телок, которым скармливали тритикалево-виковую смесь зеленой массы и сена.

Для создания стабильных запасов продовольствия, увеличения объемов производства скота и улучшения его качества используются высокопродуктивные кормовые культуры для производства зеленых кормов, силоса, сенажа и сена. Но приоритетность этих культур с точки зрения эфрфективности землепользования, снижения энергозатрат, трудовых и материальных ресурсов недостаточно учитывается.

В связи с этим целью работы было выяснить влияние зеленой массы и сена тритикалево-виковой смеси на обменные процессы в организме ремонтных телок.

Задачи исследования: 
- установить оптимальное соотношение высева зерна тритикале в смеси с викой на урожай зеленой массы и сена;

- проанализировать морфологические и биохимические показатели крови ремонтных телок.

Исследования проводились в АФ «Днестровская» Арцызского района Одесской области на ремонтных телках украинской красной молочной породы. Эксперимент по выращиванию ремонтных телок в возрасте от 8 до 12 месяцев длился до 90 дней. Разница в кормлении заключалась в том, что экспериментальной группе животных давали сено и зеленый корм тритикале - виковой смеси, а контрольной - сено и зеленый корм тритикале.

Сено и зеленый корм оценивали органологическим методом. В ходе эксперимента использовалась корма высокого качества, первого класса, как в контрольной, так и в экспериментальной группе.

Сухое вещество зеленых кормов по содержанию энергии и питательных веществ сходно с концентрированным кормом, а по биологической ценности и содержанию биологически активных веществ оно значительно доминирует.

Сено и зеленый корм содержали высококачественный белок, легко усваиваемые углеводами, жирные кислоты, витамины (особенно богатые каротином и комплексом витаминов $E$ и B), минералы и биологически активные вещества. К тому же зеленый корм имеет диетические свойства.

Питательная ценность зеленой массы зависит от фразы вегетации, ботанического состава травостоя, климатических условий и почв. По мере прохождения фраз вегетации в растениях уменьшается содержание протеина и жира и растет количество клетчатки и БЭР. На ранних стадиях вегетации она характеризуется высокой концентрацией энергии и переваримости питательных веществ, больще содержание переваримого протеина, жира, крахмала, сахара, микроэлементов и витаминов.

Скармливание тритикалево-виковой смеси зеленой массы и сена в рационах ремонтных телок опытной группы обеспечило, по сравнению с аналогичными показателями у контрольных животных, повешение в крови кальция на 3,19\%, неорганического фросфора на 2,48\%, каротина на 11,3\%.

Содержание общего белка в крови телок опытной группы оказался выше на 5,19 г / л, по сравнению с контрольной группы. Данные указывают на более интенсивный обмен веществ в организме молодняка крупного рогатого скота под влиянием изучаемого фактора - скармливание тритикалево-виковой смеси. Проведенные исследования показали, что включение в рационы ремонтных телок тритикалево-виковых смесей сена и зеленой массы (в фазу бутанизации и цветения) не вызывало нарушения фризиологического состояния, обмена веществ и вредного воздействия на организм в целом.

ключевые слова: тритикале, вика, смесь, ремонтные телки.

\title{
ФІЗІОЛОГІЧНИЙ СТАН ТА БІОХІМІЧНІ ПОКАЗНИКИ КРОВІ РЕМОНТНИХ ТЕЛИЦЬ ПРИ ВИКОРИСТАННІ В РАЦІОНАХ ТРИТИКАЛЕВО-ВИКОВОЇ СУМІШКИ
}

\author{
Г. І. Котець, Т. Д. Пушкар, К. Р. Мажиловська, К. О. Хамід \\ Одеський державний аграрний університет, Одеса, Україна
}

Досліджено біохімічні показники крові ремонтних телиць, яким згодовували тритикалево-викову сумішку зеленої маси та сіна.

Наведені дані вказують на більш інтенсивний обмін речовин в організмі молодняку великої рогатої худоби під впливом вивчаємого фрактора - згодовування тритикалево-викової сумішки.

ключові слова: тритикале, вика, суміш, ремонтні телиці.

\section{Вступ}

Актуальність теми. 3 метою створення стабільної кормової бази, нарощування обсягів виробництва тваринницької продукції та підвищення ії якості, застосовують високоврожайні кормові культури для виробництва 
зеленої маси, силосу, сінажу, сіна. Але при цьому недостатньо враховують ступінь пріоритетності цих культур з точки зору ефективності використання земельних ресурсів, зменшення затрат енергії, праці та матеріальних засобів. Як свідчать літературні дані в цьому відношенні заслуговує серйозної уваги злаково-бобова сумішка, яка включає тритикале з викою. (Hnoievyi, 2006, с. 400)

Аналіз останіх досліджень і публікацій свідчать, що висока ефективність застосування зелених кормів досягається за впровадження у виробництво системи злаково-бобових сумішок, що використовуються як на зелений корм, так і для заготівлі сіна, сінажу і силосу. (Trishyn, 2016, с. 116)

Мета роботи - метю роботи було зясувати вплив зеленої маси та сіна тритикалево-викової сумішки на обмінні процеси в організмі ремонтних телиць.

Завдання дослідження:

- всановити оптимальне співвідношення висіву зерна тритикале в суміші з викою на уржай зеленої маси та сіна;

- проаналізувати морфологічні і біохімічні показники крові ремонтних телиць.

\section{Матеріал і методи досліджень}

Дослідження проводились у 2018 році в умовах АФ ТОВ «Дністовська» Арцизького району Одеської області на ремонтних теличках української червоної молочної породи. Лаболаторні дослідження з вивчення органолептичних показників і хімічного складу сумішок проводили в профрільній лаболаторії ветеринарної медицини Одеського державного аграрного університету за схемою, наведеною в таблиці 1.

Під час досліджень було вивчено оптимальні співвідношення компонентів при використанні тритикале в суміші 3 викою, які забеспечують максимальний вихід поживних речовин з одиниці площі.

Дослід з вирощування ремонтних телиць з 8 до 12 місячного віку продовжувався 90 днів. Різниця в годівлі була в тому, що тварини дослідної групи отримували сіно та зелену масу тритикале-викових сумішок, а контрольної - сіно та зелену масу тритикале.

Таблиця 1

Схема лабораторних дослідів

\begin{tabular}{|c|c|c|}
\hline № варіанта & Показник & Співвідноення \\
\hline 1 & Вика & 100 \\
\hline 2 & Тритикале & $50: 50$ \\
\hline 3 & Тритикале - вика & $60: 40$ \\
\hline 4 & Тритикале - вика & $70: 30$ \\
\hline 5 & Тритикале - вика & $80: 20$ \\
\hline 6 & Тритикале - вика & $90: 10$ \\
\hline 7 & Тритикале - вика & \\
\hline
\end{tabular}

Безпосередньо перед згодовуванням сіно та зелену масу оцінювали органолептичним методом. Протягом досліду використовувалась корми, як в контрольній так і в дослідній групах, високої якості, які відповідали вимогам першого класу.

В сіні та зелених кормах сумішок містилися поживні речовини, життєво необхідні для всіх тварин: протеїн високої якості, легко фрерментативні вуглеводи, незамінні жирні кислоти, вітаміни (особливо багаті на каротин і вітаміни E та групи В), мінеральні та біологічно активні речовини. До цього ж зелені корми мають дієтичні властивості.

Суха речовина зелених кормів за енергетичною поживністю і вмістом перетравного протеїну близька до концентрованих кормів, при цьому за біологічною цінністю і вмістом біологічно активних речовин значно їх переважає.

Поживна цінність зеленої маси залежить від фази вегетації, ботанічного складу травостою, кліматичних умов і ґрунтів. В міру проходження фраз вегетації в рослинах зменшується вміст протеїну і жиру та зростає кількість клітковини і БЕР. На ранніх стадіях вегетації вона характеризується вищою концентрацією енергії та перетравністю поживних речовин, більшим вміст перетравного протеїну, жиру, крохмалю, цукру, мікроелементів та вітамінів. Кров для досліджень відбирали із яремної вени від трьох тварин із групи вранці до годівлі. При вивченні біохімічного складу крові 
досліджували кількість фосфору, кальцію, каротину, резервну лужність, загальну кількість білка. Кількість Фосфору в сироватці крові визначали за Бріксом, а Кальцію - трилонометричним методом. (Borisenko, Baranova, \& Lisitsyin, 1984, с. 265)

Вміст каротину в сироватці крові визначали за Рачевським калориметричним методом, резервну лужність за методикою Неводова. (Smirnov, Konopelko, Postnikov, 1981, с. 447)

Загальну кількість білка в сироватці крові визначали рефрактометричним методом на рефрактометрі РлУ.

\section{Результати та їх обговорення.}

Фізіологічні параметри організму теличок усіх груп знаходились в межах допустимої норми. Температура тіла коливалася від 38 до 38,6 C, частота пульсу в одну хвилину 77-82, дихання 25-29, жуйка 48-51, великої різниці між тваринами не спостерігалось.

Таблиця 2

Біохімічний склад крові теличок, в середньому по групах (M $\pm \mathrm{m}, \mathrm{n}=3$ )

\begin{tabular}{|c|c|c|c|}
\hline \multirow{2}{*}{ Показники } & \multicolumn{2}{|c|}{ Групи } \\
\cline { 2 - 4 } & контрольна & дослідна & \pm до контролю, \% \\
\hline Кальцій, ммоль/л & $2,82 \pm 0,05$ & $2,91 \pm 0,04$ & $+3,19$ \\
\hline неорганічний Фосфор, ммоль/л & $1,61 \pm 0,01$ & $1,65 \pm 0,02$ & $+2,48$ \\
\hline каротин., мг. \% & $0,53 \pm 0,01$ & $0,59 \pm 0,02$ & $+11,3$ \\
\hline резервна лужність., об.\% $\mathrm{CO}_{2}$ & $47,81 \pm 1,14$ & $49,72 \pm 1,17$ & $+4,0$ \\
\hline загальний білок, г/л & $77,49 \pm 1,35$ & $81,51 \pm 1,60 *$ & $+5,19$ \\
\hline
\end{tabular}

За зовнішнім виглядом телички мали нормальний волосяний покрив, але у тварин дослідної групи волосяний покрив відрізнявся особливим блиском.

Результати дослідів біохімічних показників крові ремонтних теличок, які отримували злакову та злаково-бобову сумішку наведено в таблиці 2.

Встановлено, що використання тритикалево-викової сумішки в раціонах ремонтного молодняку дослідної групи зумовило, у порівнянні з аналогічними показниками у контрольних тварин, збільшення в крові Кальцію на 3,19 \%, неорганічного Фосфрору на 2,48 \%, каротину на 11,3 \%. Вміст загального білку в крові теличок дослідної групи виявився вищим на 5,19 г/л проти контрольної групи.

Наведені дані вказують на більш інтенсивний обмін речовин в організмі молодняку великої рогатої худоби під впливом вивчаємого фрактора - згодовування тритикалево-викової сумішки.

\section{Висновки}

Проведені дослідження показали, що включення у раціони ремонтних телиць тритикалево-викових сумішок сіна та зеленої маси (у фази бутанізації та цвітіння) не викликало порушення фрізіологічного стану, обміну речовин та шкідливої дії на організм в цілому.

\section{References}

Bohdanov, H. O., Kandyba, V. M., \& Ibatullin, I. I. (2012). Monohrafiia. Zhytomyr: PP «Ruta». (in Ukrainian)

Bohdanov, H. O., Kandyba, V. M., \& Ibatullin, I. I. (2012). Norma i ratsiony povnotsinnoi hodivli vysokoproduktyvnoi velykoi rohatoi khudoby. Kyiv: Ahrarna nauka. (in Ukrainian)

Borisenko, E. Ya., Baranova, K. V., \& Lisitsyin, A. P. (1984). Praktikum po razvedeniyu selskohozyaystvennyih zhivotnyih. Moskva: Kolos. (in Russian)

Hnoievyi, I. V., \& Trishyn, O. K. (2007). Metodychno-praktychnyi posibnyk. Kharkiv: Mahda LTD. (in Ukrainian) Hnoievyi, I. V., (2006). Monohrafiia. Kharkiv: Mahda ILT. (in Ukrainian) 
Hnoievyi, V. I. (2015). Rozrobka i vprovadzhennia u vyrobnytstvo tsilorichno odnotypnoi hodivli molochnoi khudoby v Ukraini. Problemy zooinzhenerii ta veterynarnoi medytsyny, 31(1), 154-165. (in Ukrainian)

Hnoievyi, V. I., Ilchenko, O. M., Hnoiovyi, I. V., \& Rozdaibeda, Yu. O. (2006). Prioritetni zlakovo-bobovi sumishky na sylos i zernosinazh. Kormy i kormo vyrobnytstvo, 57, 116-123. (in Ukrainian)

Omelyanenko, A. A. (1981). Kruglogodovoe odnotipnoe kormlenie skota. Zhivotnovodstvo, 6, 36-38. (in Russian)

Omelyanenko, A. A. (1991). Kontseptsiya razvitiya zhivotnovodstva na Ukraine. Zhivotnovodstvo, 7, 2-5. (in Russian)

Smirnov, A. M., Konopelko, P. Ya., Postnikov, V. S. (1981). Klinicheskaya diagnostika vnutrennih nezaraznyih bolezney selskohozyaystvennyih zhivotnyih. Leningrad: Kolos. (in Russian) 